\title{
THE END OF EMPIRE: NEW RADIOCARBON DATES FROM THE AYACUCHO VALLEY, PERU, AND THEIR IMPLICATIONS FOR THE COLLAPSE OF THE WARI STATE
}

\author{
Brian Clifton Finucane ${ }^{1} \bullet \mathrm{J}$ Ernesto Valdez ${ }^{2} \bullet$ Ismael Pérez Calderon $^{3} \bullet$ \\ Cirilo Vivanco Pomacanchari ${ }^{4} \bullet$ Lidio M Valdez $^{5} \bullet$ Tamsin O'Connell $^{6}$
}

\begin{abstract}
This paper presents a suite of new accelerator mass spectrometry (AMS) radiocarbon measurements from the Ayacucho Valley of Peru and discusses their implications for the timing and nature of the collapse of the Wari Empire. Analysis of these and previously published dates from the region indicate that there is little evidence for state political authority in Ayacucho prior to the end of the 7th century. Dated human remains from the polity's eponymous capital indicate that the authority of the state's rulers persisted at least as late as the mid-11th century. Dates from rural sites in the Ayacucho Valley suggest continuity of occupation and folk material culture following Wari's disintegration. Finally, AMS measurements of bone from 2 large extramural ossuaries represent the first absolute dates associated with Chanca ceramics and suggest that this archaeological/ethnohistoric culture appeared in the valley at about AD 1300.
\end{abstract}

\section{INTRODUCTION}

The Ayacucho Valley in the semi-arid central highlands of Peru was one of 3 regions of the Central Andes in which urban, state societies developed during the 1st millennium AD (Stanish 2001; see Figure 1). During the stylistic phase known as the Middle Horizon, the material correlates of state society appear in Ayacucho for the first time. These indicators include the modality of the valley's settlement hierarchy, evidence for social stratification, and the hyperurban site of Huari, considered the capital of the eponymous polity ${ }^{7}$ (Isbell and Schreiber 1978; Isbell et al. 1991; Schreiber 1992). With an architectural core of 250 ha and a residential periphery of at least equal size, Huari is thought to have been occupied by at least $\sim 10,000-30,000$ individuals (Isbell et al. 1991).

The Wari state is considered to have been an empire due to the intrusion of its distinctive architectural forms - such as D-shaped temples, cellular orthogonal administrative complexes, and patio groups-into distant regions of the Central Andes (Schreiber 1992). Wari established colonies at Jincamocco in the Sondondo Valley, at Cerro Baul in Moquegua, and Pikillacta in Cuzco (McEwan 1991; Schreiber 1992; Willams et al. 2001).

Between about AD 500-1000, the cities of Huari and Tiahuanaco were the foci for the dispersal of 2 distinct variants of the Middle Horizon's style and iconography, and the presence of these diagnostic styles in a region is frequently equated with the rule of one of these polities. In this paper, we wish to emphasize the distinction between the temporal blocks characterized by stylistic unity and political hegemony. Though the emergence and persistence of Middle Horizon styles and Tiahuanacoid

\footnotetext{
'Research Laboratory for Archaeology and the History of Art, Dyson Perrins Building, South Parks Rd, Oxford OX1 3QY, United Kingdom. Currently at: Department of Animal Science, 816 Garrigus Building, University of Kentucky, Lexington, Kentucky 40546, USA. Corresponding author. Email: brian.finucane@gmail.com.

2Jíron Bolognesi 321, Chuto Pila, Huanta, Ayacucho, Peru.

${ }^{3}$ Universidad Nacional de San Cristóbal de Huamanga, Facultad de Ciencias Sociales, Escuela de Formación Profesional de Arqueología e Historia, Ayacucho, Peru.

${ }^{4}$ Universidad Nacional de San Cristóbal de Huamanga, Facultad de Ciencias Sociales, Escuela de Formación Profesional de Arqueología e Historia, Ayacucho, Peru.

${ }^{5}$ Department of Anthropology, University of Victoria, Victoria British Columbia, Canada.

${ }^{6}$ Department of Archaeology, University of Cambridge, Cambridge CB2 3DZ, United Kingdom.

${ }^{7}$ The orthography used in this investigation follows Isbell (2001). The archaeological site in Ayacucho is spelled "Huari," whereas the polity is "Wari."
} 


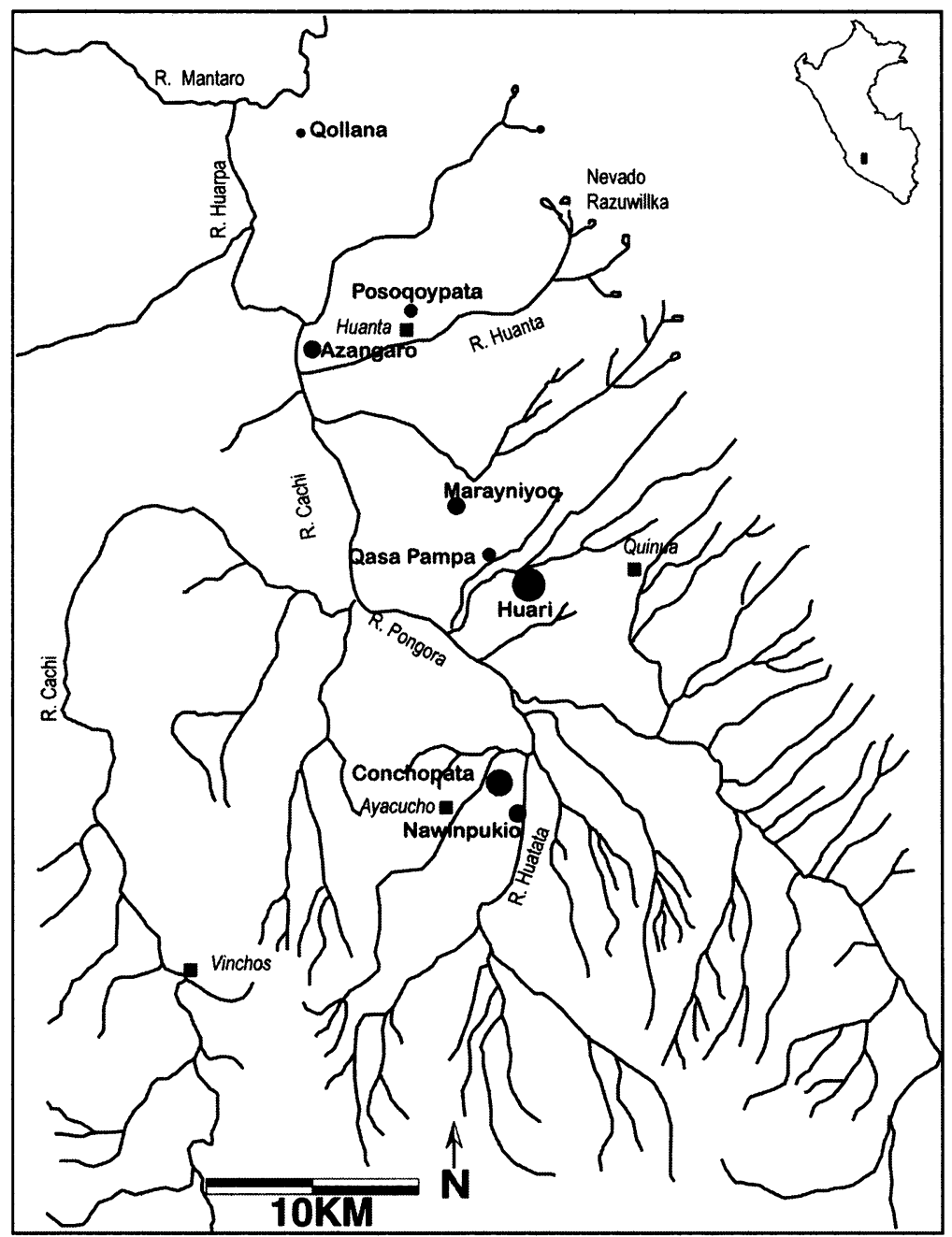

Figure 1 Map of the Ayacucho Valley showing the location of archaeological sites mentioned in the text, as well as modern towns. The location of the Ayacucho Valley within Peru is indicated in the upper right-hand corner.

iconography may or may not coincide with developments in the realm of politics, the construction, use, and abandonment of planned architecture is likely to signal the extent and duration of political authority.

The material dated in this study can be divided between samples pertaining to elite or Wari administrative contexts and those from non-elite, non-administrative contexts, both urban and rural. Samples from the former group provide termini post quo for the construction and use of state facilities and termini ante quo for their abandonment, whereas the latter reflect the degree of cultural continuity in the countryside, including the stability of settlement and burial patterns. Of particular interest is the persistence of Wamanga ${ }^{8}$ ceramics, which are the sub-elite wares of Wari's imperial heartland,

\footnotetext{
${ }^{8}$ Throughout this article the spelling "Wamanga" will be used to refer to the ceramic style, whereas "Huamanga" refers to the time period immediately following the collapse of the Wari state.
} 
dominating the ceramic assemblages at both rural and urban sites, and the appearance of ceramic styles attributed by Lumbreras (1974) to the protohistoric Chanca.

\section{METHODS AND MATERIALS}

All samples were prepared for accelerator mass spectrometry (AMS) radiocarbon dating at the Oxford Radiocarbon Accelerator Unit (ORAU) using the laboratory's routine collagen extraction procedure, including an ultrafiltration pretreatment step, which retains only the weight fraction of gelatinized collagen $>30 \mathrm{kD}$. (Bronk Ramsey et al. 2004). The lighter weight fraction removed by ultrafiltration may contain salts, degraded collagen, and environmental contaminants of different ${ }^{14} \mathrm{C}$ age than the gelatinized collagen. Only samples of bone yielding $10 \mathrm{mg} / \mathrm{g}$ or more of collagen were considered for dating. The $\mathrm{C}: \mathrm{N}$ ratios of collagen were also used to assess collagen preservation. All samples dated had $\mathrm{C}: \mathrm{N}$ ratios between 2.9-3.6, consistent with modern bone collagen (DeNiro 1985).

In this study, we have elected to use the IntCal04 calibration curve based on the atmospheric data from the Northern Hemisphere, rather than the Southern Hemisphere calibration curve (SHCal04; McCormac et al. 2004). This decision is based on the fact that during the growing season of the plants consumed by the people and animals of the Ayacucho (that is, the austral summer), the Ayacucho Valley lies within the Intertropical Convergence Zone (ITCZ). Therefore, the carbon dioxide taken up during photosynthesis is more likely representative of the Northern than the Southern Hemisphere atmosphere (McCormac et al. 2004).

All calibrations, calculations, and modeling were conducted using the OxCal v 3.10 program (Bronk Ramsey 1995, 2001). The OxCal model for Ayacucho's political prehistory contains a sequence of 3 phases, Pre-Wari, Wari, and Post-Wari, and the posterior distributions and boundaries were determined using Bayes' theorem and Markov chain Monte Carlo sampling. ${ }^{14} \mathrm{C}$ dates grouped within each phase are assumed to be uniformly distributed between the phase boundaries in Poisson distributed intervals (Bronk Ramsey 2001).

The dated samples, presented in Table 1, represent a subset of a larger series analyzed as part of the Ayacucho Archaeo Isotope Project in order to provide an absolute chronology for dietary change in Ayacucho. Human bone is a less than ideal substrate for constructing a ${ }^{14} \mathrm{C}$ chronology due to its slow turnover and the possible incorporation through diet of carbon from multiple reservoirs with uncertain age offsets. However, this new series of 14 AMS measurements represents a significant addition to the small corpus of ${ }^{14} \mathrm{C}$ dates available for the Wari heartland and therefore a potentially valuable resource if evaluated critically. As the Ayacucho Valley is situated in the highlands at $>2500 \mathrm{~m}$, far from any large bodies of water, the confounding impact of marine and lacustrine reservoirs is considered to be minimal.

\section{RESULTS}

Three of the dated samples come from cut stone tombs, 2 from Huari and 1 from the site of Marayniyoq. Material was dated from the catacombs of the Mongachayoq Sector of the capital city. Mongachayoq is comprised of a 4-story subterranean complex of tunnels, chambers, and shafts constructed using both ashlar and fieldstone masonry. Based on the labor invested in their construction, Isbell (2004) argues that these tombs housed the remains of Wari's emperors. The 2 samples pertain to the second subterranean level, below the galleries of Level 1, and a D-Temple on the ground. The human remains were associated with fragments of Viñaque and Ocros pottery, exotic shell, and silver and gold plates (Perez 2000). The earlier of the 2 dated samples from the Mongachayoq Sector 
Table 1 Details of ${ }^{14} \mathrm{C}$ results presented for the first time in this study. All samples listed are human bone. Period designations indicate association of the samples with Wari architecture, Middle Horizon-Huamanga ceramics, of Chanca-style ceramics.

\begin{tabular}{|c|c|c|c|c|c|c|c|}
\hline OxA- & $\begin{array}{l}\text { Archaeological } \\
\text { context }\end{array}$ & Site type & $\begin{array}{l}\text { Context } \\
\text { type }\end{array}$ & $\begin{array}{l}{ }^{14} \mathrm{C} \text { age } \\
\mathrm{BP}\end{array}$ & $\begin{array}{l}\delta^{13} \mathrm{C} \\
(\%)\end{array}$ & $\begin{array}{l}68.2 \% \\
\text { cal AD }\end{array}$ & Period \\
\hline 15281 & $\begin{array}{l}\text { Huari } \\
\text { Monqachayoq, } \\
\text { EA 7, Level C }\end{array}$ & Capital & $\begin{array}{l}\text { Ashlar } \\
\text { tomb }\end{array}$ & $948 \pm 27$ & -8.8 & $1020-1160$ & Wari \\
\hline 15280 & $\begin{array}{l}\text { Huari } \\
\text { Monqachayoq } \\
\text { EA 14, Level C }\end{array}$ & Capital & $\begin{array}{l}\text { Ashlar } \\
\text { tomb }\end{array}$ & $1237 \pm 27$ & -15.8 & $690-860$ & Wari \\
\hline 15585 & $\begin{array}{l}\text { Marayniyoq } \\
\text { Sector S4E5, } \\
\text { Level } 1\end{array}$ & Town & $\begin{array}{l}\text { Ashlar } \\
\text { tomb }\end{array}$ & $931 \pm 28$ & -9.0 & $1030-1160$ & Wari \\
\hline 15584 & $\begin{array}{l}\text { Marayniyoq } \\
\text { Sector N1E4-5 }\end{array}$ & Town & $\begin{array}{l}\text { Mortuary } \\
\text { structure }\end{array}$ & $1013 \pm 28$ & -10.8 & 990-1030 & Wari \\
\hline 15382 & $\begin{array}{l}\text { Qasa Pampa, } \\
\text { EA 10, Context 3, } \\
\text { Burial 2 }\end{array}$ & Village & Tomb & $886 \pm 27$ & -10.4 & $1050-1210$ & $\begin{array}{l}\text { MH } \\
\text {-Huamanga }\end{array}$ \\
\hline 15383 & $\begin{array}{l}\text { Qasa Pampa, } \\
\text { EA 15, Tomb } 4\end{array}$ & Village & $\begin{array}{l}\text { Cist burial, } \\
\text { below } \\
\text { D-structure }\end{array}$ & $1269 \pm 28$ & -11.8 & $685-775$ & $\begin{array}{l}\text { MH } \\
\text {-Huamanga }\end{array}$ \\
\hline 15577 & $\begin{array}{l}\text { Posoqoypata, } \\
\text { Recinto 17, } \\
\text { Burial B }\end{array}$ & Village & Cist burial & $843 \pm 26$ & -14.8 & $1165-1225$ & $\begin{array}{l}\text { MH } \\
\text {-Huamanga }\end{array}$ \\
\hline 15578 & $\begin{array}{l}\text { Posoqoypata, } \\
\text { Tomb } 15\end{array}$ & Village & $\begin{array}{l}\text { Mortuary } \\
\text { structure }\end{array}$ & $813 \pm 26$ & -8.1 & $1210-1260$ & $\begin{array}{l}\text { MH } \\
\text {-Huamanga }\end{array}$ \\
\hline 15374 & $\begin{array}{l}\text { Azangaro } \\
\text { Southern Sector } \\
\text { Probe 18.63, } \\
\text { Stratum IV }\end{array}$ & $\begin{array}{l}\text { Administrative } \\
\text { facility }\end{array}$ & Tomb & $616 \pm 26$ & -12.0 & 1295-1395 & Post-Wari \\
\hline 15375 & $\begin{array}{l}\text { Azangaro } \\
\text { Central Sector } \\
\text { Probe } 13.4, \\
\text { Stratum III }\end{array}$ & $\begin{array}{l}\text { Administrative } \\
\text { facility }\end{array}$ & Corridor & $694 \pm 28$ & -10.7 & $1270-1380$ & Post-Wari \\
\hline 15582 & Qollana & Ossuary & & $633 \pm 32$ & -10.0 & $1295-1390$ & Chanca \\
\hline 15583 & Qollana & Ossuary & & $696 \pm 28$ & -11.0 & $1270-1380$ & Chanca \\
\hline 15278 & $\begin{array}{l}\text { Huari- } \\
\text { Vegachayoq } \\
\text { Moqo, Burial } 14\end{array}$ & Capital & $\begin{array}{l}\text { Secondary } \\
\text { interment }\end{array}$ & $477 \pm 24$ & -10.6 & $1420-1445$ & $\begin{array}{l}\text { Post-Wari } \\
\text { Chanca }\end{array}$ \\
\hline 15279 & $\begin{array}{l}\text { Huari- } \\
\text { Vegachayoq } \\
\text { Moqo, Burial } 14\end{array}$ & Capital & $\begin{array}{l}\text { Secondary } \\
\text { interment }\end{array}$ & $562 \pm 27$ & -11.5 & $1320-1415$ & $\begin{array}{l}\text { Post-Wari } \\
\text { Chanca }\end{array}$ \\
\hline
\end{tabular}

(OxA-15280) yielded a date of $1237 \pm 27 \mathrm{BP}$, or cal AD 690-860 (68.2\%). The later sample from Mongachayoq (OxA-15281) produced a date of $929 \pm 28 \mathrm{BP}$, or cal AD 1020-1160 (68.2\%). The span represented by these dates was calculated as $250-400 \mathrm{yr}(68.2 \%)$.

The third dated sample of bone from an elite context comes from the site of Marayniyoq. Located on the southern rim of the Huanta Basin, Marayniyoq is the only site in the Ayacucho Valley apart from Huari with ashlar tombs. Human bone (OxA-15584) from a tomb in the southeast corner produced a date of $931 \pm 28 \mathrm{BP}$, or cal AD 1030-1160 (68.2\%), suggesting that the use of this structure coincided with that of Mongachayoq. An additional sample of bone from a fieldstone mortuary in the northeast corner of the excavated portion of the site dates to $1013 \pm 28 \mathrm{BP}$, or cal AD 990-1030 (OxA-15585). These dates represent a span of no more than $65 \mathrm{yr}(68.2 \%)$. 
The human remains from the Wari administrative center of Azangaro in the Huanta Basin provide a date by which this state facility was abandoned (Figure 2). This 7.5-ha site was constructed by the Wari state within the prime farmland of the Huanta Basin as a storage complex for maize and a barracks to house laborers (Anders 1991; Schreiber 1992). Some 95\% of the ceramics are of the Wamanga style (Anders 1986).

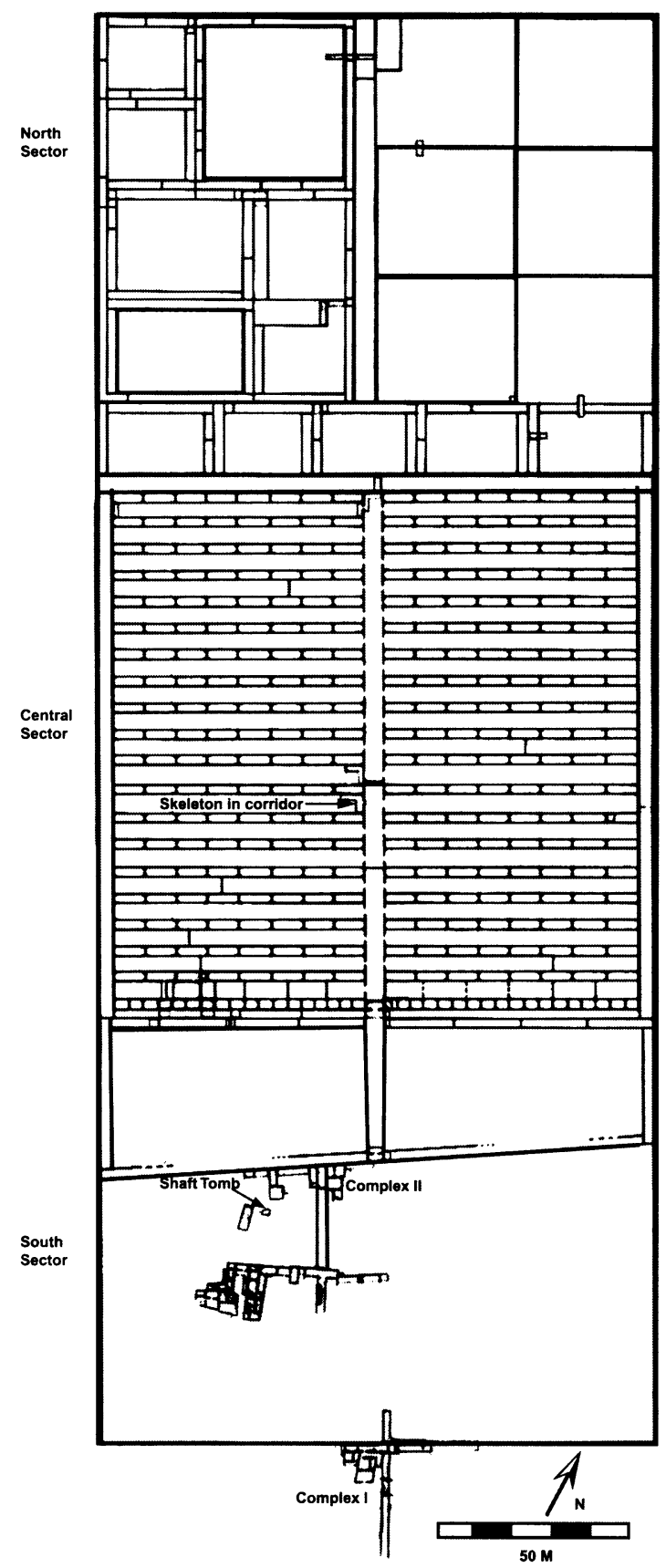

Figure 2 Map of Azangaro showing the location of the dated remains from the Shaft Tomb in the South Sector and the skeleton from the Central Sector. Map redrawn after Figure 3 by Anders (1991). 
The first dated sample comes from a skeleton recovered in a corridor within the Central Sector of the site. The dated human remains were not buried but deposited above the floor in what Anders (1986: 616) termed "a rapid abrupt abandonment of the site," following the ransacking of the storerooms. These remains thus provide a date by which this corridor and sector of the site were out of use. The date (OxA-15375) for this skeleton indicates the storerooms of Azangaro were abandoned by at least $694 \pm 28 \mathrm{BP}$, or cal AD 1270-1380 (68.2\%).

The second sample of human bone dated from Azangaro pertains to a shaft tomb in the South Sector of the site. The tomb is situated amongst a complex of irregular agglutinated buildings appended to the perimeter walls of the planned architectural compounds. The ${ }^{14} \mathrm{C}$ date $(\mathrm{OxA}-15374)$ for these remains indicates that they were buried after $616 \pm 26 \mathrm{BP}$, or cal AD 1295-1395 (68.2\%). Using the Order command in $\mathrm{OxCal} \vee 3.10$ shows that there is an $80 \%$ probability that these remains postdate those in the corridor. The time span represented by these dates is between 5 and $85 \mathrm{yr}(68.2 \%)$.

The details of additional ${ }^{14} \mathrm{C}$ dates from construction and occupation contexts at Azangaro, originally presented by Anders (1986), are listed in Table 2 . The time span of these dates was calculated as $160-380 \mathrm{yr}(68.2 \%)$.

Table 2 Details of ${ }^{14} \mathrm{C}$ assays from Azangaro originally presented by Anders (1986).

\begin{tabular}{llllll}
\hline Beta & $\begin{array}{l}\text { Archaeological } \\
\text { context }\end{array}$ & $\begin{array}{l}\text { Context } \\
\text { type }\end{array}$ & $\begin{array}{l}\text { Sample } \\
\text { type }\end{array}$ & $\begin{array}{l}{ }^{14} \mathrm{C} \text { age } \\
\text { BP }\end{array}$ & $\begin{array}{l}68.2 \% \\
\text { cal AD }\end{array}$ \\
\hline 1876 & $\begin{array}{l}\text { Central Sector } \\
\text { Complex IV, } \\
\text { Corridor 19w, }\end{array}$ & Hearth & Pooled charcoal & $1190 \pm 75$ & $710-950$ \\
1874 & $\begin{array}{l}\text { Stratum 2 } \\
\text { Central Sector } \\
\text { Corridor 20e, } \\
\text { Stratum 5 } \\
\text { South Sector } \\
\text { Complex II, } \\
\text { Room 18.2, } \\
\text { Stratum 3 }\end{array}$ & $\begin{array}{l}\text { Construction layer } \\
\text { fill }\end{array}$ & Pooled charcoal & $1070 \pm 50$ & $890-1020$ \\
\hline 875 & & & $960 \pm 65$ & $970-1220$ \\
\hline
\end{tabular}

Two sites in the Huanta Basin attest to the longevity of the Wamanga style in the region. At the site of Qasa Pampa, 98\% of the sherds belong to the Wamanga style (Vivanco et. al. 2003). The earlier Qasa Pampa remains were interred beneath a D-shaped structure and yielded a calibrated date (OxA-15383) of AD 685-775 (68.2\%). The later human remains from Qasa Pampa were entombed with a fieldstone and masonry mortuary structure and yielded a calibrated date (OxA-15382) of AD $1050-1210(68.2 \%)$. These dates cover a span of 350-500 yr (68.2\%).

Wamanga ceramics were also the predominant style at the village of Posoqoypata, $10 \mathrm{~km}$ to the north of Qasa Pampa (Valdez 2003a). Human remains were dated from a subfloor burial containing Wamanga vessels within Recinto 17 of the site (Figure 3). The calibrated date (OxA-15578) reveals the continued use of such Middle Horizon-style ceramics as late as AD 1165-1225 (68.2\%). The second sample dated a flexed burial in the central area of the site. These skeletal remains yielded a calibrated date (OxA-15577) of AD 1210-1260 (68.2\%). The Posoqoypata dates cover a span of no more than $55 \mathrm{yr}(68.2 \%)$. 


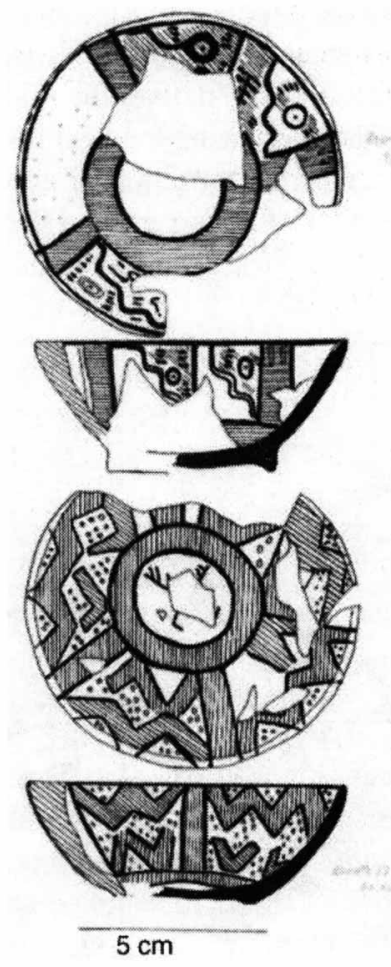

Figure 3 Huamanga-style bowl recovered from a burial in Recinto 17 of Posoqoypata. Drawing by Ernesto Valdez.

Further north in the Huanta Basin, grave robbers unearthed a cylindrical semi-subterranean mausoleum at the site of Qollana unassociated with any known prehistoric settlement. In addition to the remains of 129 individuals, the ossuary also contained coarse ceramics belonging to the Arqalla and Aya Orjo styles. Lumbreras (1974) associates both styles with the protohistoric Chanca, early rivals of the Inca who occupied Ayacucho and Andahuaylas. The 2 samples of bone (OxA-15581, OxA15582 ) indicate the ossuary was in use during the late 13th through 14th century for no more than $100 \mathrm{yr}(68.2 \%)$.

Grave 14 of Huari's Vegachayoq Moqo Sector represents a destructive intrusion into one of the city's walls that contained the commingled remains of at least 96 men, women, and children displaying 4 types of artificial cranial deformation (Bragayrac 1991; Tiesler Blos 1994). As artificial cranial deformation served as an indicator of ethnicity in the Andes at the time of the Spanish conquest, Grave 14 likely represents a polyethnic sepulcher. The burial also contained coarse post-Wari ceramics attributed to the protohistoric Chanca (Bragayrac 1991). The 2 samples of bone analyzed yielded dates of $477 \pm 24 \mathrm{BP}(\mathrm{OxA}-15278)$ and $562 \pm 27 \mathrm{BP}$ (OxA-15279), which calibrate to AD 1420-1445 and 1320-1415 (68.2\%), respectively. These dates cover a span of 15-115 yr (68.2\%).

\section{DISCUSSION}

The dates presented in this paper, in conjunction with a re-analysis of earlier ${ }^{14} \mathrm{C}$ assays, have implications for both the duration of Wari's rule and the nature of its collapse. A timeline of Ayacucho Valley's political prehistory construction based on these ${ }^{14} \mathrm{C}$ dates is presented in Figure 4 and Table 3. The crucial ${ }^{14} \mathrm{C}$ assays for dating the rise and fall of centralized political authority in the region come from samples sealed below or in the construction fill of the temples and patio groups at Conchopata and Huari, which provide termini post quo for the erection of public architecture. The 
earliest dated architectural evidence for the Wari state (the semi-subterranean temple of Huari's Moraduchayoq Sector) pertains to the mid-7th century, whereas the latest evidence for elite dominance, the burials within the monumental tombs of Mongachayoq, date to the mid-11th century at the earliest. The skeletal remains from Marayniyoq and the Mongachayoq Sector of Huari provide termini post quo for use of these elite mortuary contexts, whereas termini ante quo for the collapse of the Wari state are provided by the skeleton in the corridor of Azangaro and the human remains from Burial 14 of Huari's Vegachayoq Moqo Sector.

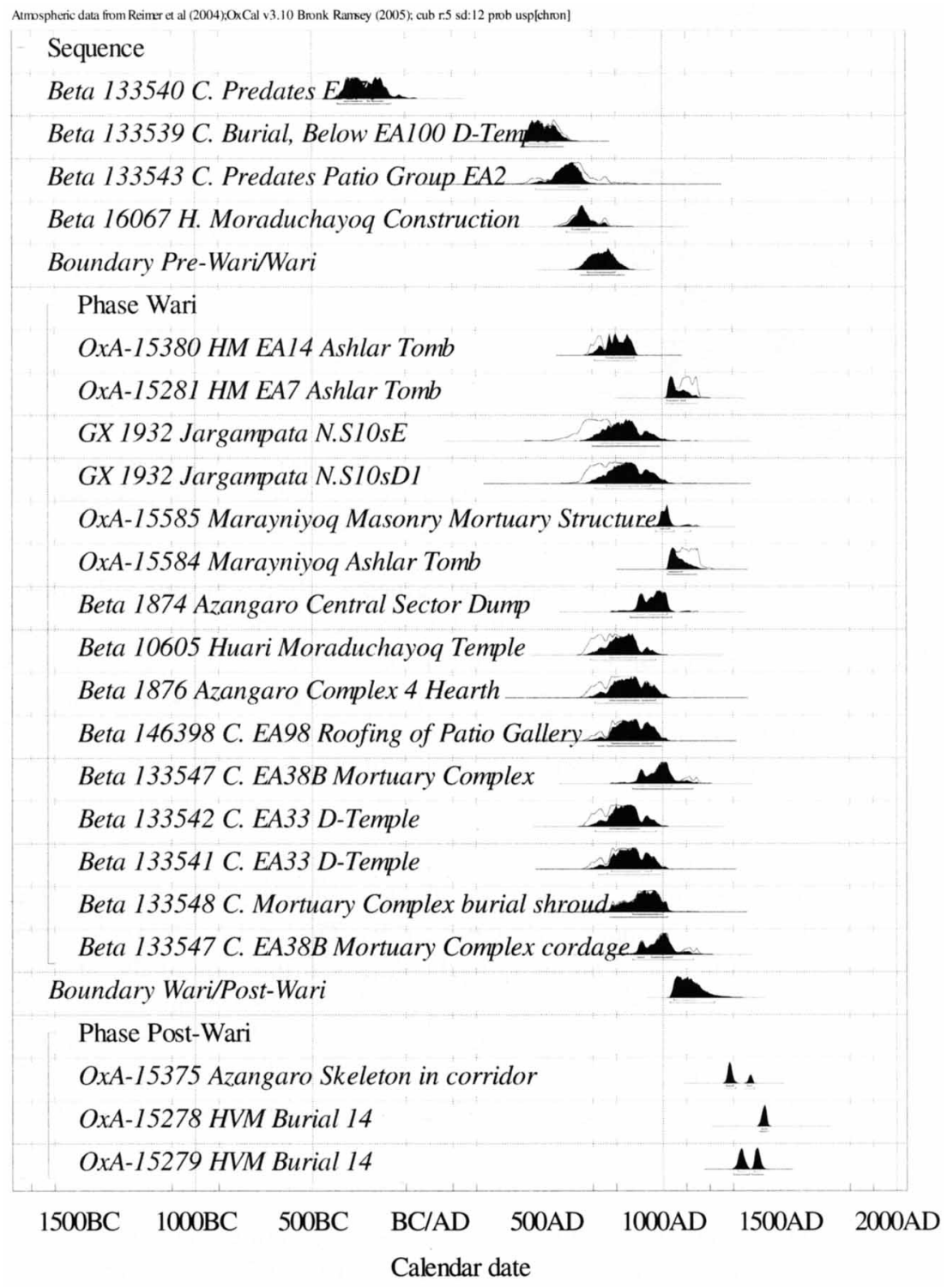

Figure 4 Calibrated ${ }^{14} \mathrm{C}$ dates associated with Wari state architecture within the Ayacucho Valley. Details of the Oxford dates are provided in Table 1 and those from Azangaro in Table 2; contextual details of other dates are provided in the original publications: C(onchopata) (Ketterman 2001); Huari Moraduchayoq (Isbell et al. 1991); Jargampata (Isbell 1977). 
Table 3 Timeline of the Ayacucho Valley's political prehistory during the millennia of the common era. Designations of temporal blocks after MacNeish et al. (1981).

\begin{tabular}{ll}
\hline $\mathrm{AD}$ & Epoch \\
\hline 1500 & Chanca \\
1400 & \\
1300 & Huamanga \\
\hline 1200 & \\
1100 & \\
1050 & Wari \\
\hline 1000 & \\
900 & \\
800 & \\
700 & AD 1195-1255(68.2\%) \\
\hline Huamanga/Chanca cultural boundary & AD 1070-1180 (68.2\%) \\
Wari/Post-Wari (Huamanga) political boundary & AD 680-790(68.2\%) \\
Pre-Wari/Wari political boundary & \\
\hline
\end{tabular}

Wari's rule endured at least as long as that of Tiwanaku. Using OxCal's phase modeling, Bruce Owen (2005) has estimated that Wari's sister polity disintegrated by the end of the 10th century. The period of elite dominance within the imperial heartland of Ayacucho is roughly coeval with the occupation of the colonies of Cerro Baul and Pikillacta, suggesting rapid imperial expansion and contraction (Glowacki 2005; Moseley et al. 2005). However, without additional chronological information from the provinces it is difficult to determine whether the end of the Wari was a seismic phenomenon, radiating outward from the imperial epicenter, or one of erosion and decay that began at the periphery and spread to the core.

This chronology for the Wari state based on ${ }^{14} \mathrm{C}$-dated construction, occupation, and abandonment of public and elite architecture within the Ayacucho Valley is at odds with chronologies for the Middle Horizon derived from ceramics, such as that presented by Isbell (2001: Figure 1). The discrepancies may signal a real delay of $\sim 100 \mathrm{yr}$ between the spread of the stylistic horizon and the onset of Wari's political hegemony, suggesting that cultural and political developments did not proceed in tandem. Alternatively, the variance between the ceramic and architectural timelines may stem from sample bias. This analysis includes only a single date (Beta-16067) for construction within the site of Huari, and therefore it is reasonable to suppose that the earliest phases of planned construction have been missed. As a result, this chronology would underestimate the antiquity of state authority in Ayacucho.

However, this ${ }^{14} \mathrm{C} /$ architectural timeline more accurately represents Wari's longevity within the Ayacucho Valley than existing ceramic chronologies. The continued use of the royal tombs at Mongachayoq into at least the 11 th century testifies to the longevity of elite authority within the capital. The ${ }^{14} \mathrm{C}$ dates from contexts postdating the abandonment of Wari architecture (i.e. Grave 14 Vegachayoq Moqo and the remains from the corridor of Azangaro) are trivial. Until additional samples are available from abandonment/destruction contexts within the capital, it will be difficult to improve the temporal resolution of the state's demise.

${ }^{14} \mathrm{C}$ evidence from rural sites in the Huanta Basin indicates that the disintegration of the Wari polity did not result in an immediate depopulation of the Ayacucho Valley. Dates from both Posoqoypata and Qasapampa document the use of mortuary structures at these sites and, by implication, occupa- 
tion of these settlements in the centuries following Wari's demise. The ${ }^{14} \mathrm{C}$ dates from these 2 sites also imply that Wamanga-style ceramics remained in use after the end of the empire, until the late 13th century. The persistence of Wamanga ceramics long after the fall of Wari implies that other sites in the Ayacucho Valley containing a Wamanga ceramic component may have been occupied after the state's demise.

Wari's collapse did not coincide with the depopulation of the Valley, a shift in settlement patterns, or major changes in sub-elite material culture (i.e. Wamanga ceramics). These changes would occur centuries after the demise of the polity. The AMS assays from Vegachayoq Moqo and Qollana provide the first absolute dates associated with Chanca-style ceramics in the Ayacucho Valley. The dates from Vegachayoq Moqo and Qollana substantiate that the ceramics identified as "Chanca" came into use long after the collapse of the Wari polity. As Luis Lumbreras (1974; see also MacNeish et al. 1981) has suggested, the adoption of Chanca-style ceramics coincides with a major upheaval in the region as the number of settlements plummets and the valley's remaining population relocates to the hilltops and the higher elevations of the tuber growing suni zone (3200-4100 m) and the puna grasslands (>4100 m) (Valdez 2003b). It is, however, clear that if one is to infer the presence of the Chanca ethnicity from "Chanca" ceramics, then a Chanca invasion of Ayacucho was not the cause of Wari's fall, as "Chanca" ceramics only appear at about AD 1300.

As epitomized by the ossuaries of Qollana and Grave 14 of Vegachayoq Moqo, there was also a profound shift in mortuary ritual in about $\mathrm{AD} 1300$. No longer are human remains interred within settlements in subfloor cists (as at Conchopata, see Isbell 2000, 2004; Finucane et al. 2006), masonry mortuary structures (as at Posoqoypata and Qasa Pampa), or ashlar tombs (as at Mongachayoq and Marayniyoq), but in extramural mortuary structures and caves (see Lumbreras 1974).

Intriguingly, the monumental architecture of the abandoned capital of Huari was appropriated for the dead in this era. It is worth mentioning that the word "Huari" translates from Quechua as "honored ancestor." In this case, the term applies not to the builders of the site but to the ruins themselves. Grave 14 may have served as an agujero creacional (place of creation, after Martínez [1983]) that was excavated into the wall of Vegachayoq Moqo, so that the remains of the genealogical kin of ancient Ayacuchanos could be incorporated into the fabric of a huaca (sacred place) that served as the fictive ancestor for multiple ethnic groups in the Ayacucho Valley and beyond. This theme will be elaborated upon at length in a future publication.

The shaft tomb in the South Sector of Azangaro may represent another such intrusive, post-occupation interment, though the excavator argues that the tomb contained the remains of Azangaro's governor or curaca (Anders 1986). If, however, the burial in the tomb and occupation of the South Sector of Azangaro were contemporaneous, then the site was inhabited by people using Wamanga ceramics until the 14 th century.

\section{RE-ASSESSING AZANGARO}

The data from Azangaro bear more directly upon continuity than collapse. Instead of reflecting a brief occupation as suggested by Anders (1986:632), the homogeneity of the ceramic assemblage may reflect stylistic conservatism and the persistence of sub-elite wares for centuries, even beyond the fall of Wari. The time span represented by Anders's (1986) ${ }^{14} \mathrm{C}$ dates covers at least $160 \mathrm{yr}$ and as many as $380 \mathrm{yr}$ (Table 2). Furthermore, the most recent date (Beta-1875), represents a terminus post quem for the construction. Stratum 3, the layer from which the dated charcoal was collected, as well as the overlying Stratum 2 contained "Wamanga, Wamanga/Wanta and Blackware style ceramics [sic]" (Anders 1986:625). As these same ceramic styles were recovered throughout the Central 
Sector as well, Anders (1986:625) argues that the occupations of the South and Central Sectors were contemporaneous and date to Menzel's (1964) Epoch 2 of the Middle Horizon, or AD 700-800.

However, as Stratum 3 represents construction fill, the occupation of room 18.2 must postdate cal AD 970-1220 (68.2\%) (see Anders 1986: Figure 8.2). Either the construction and subsequent occupation of room 18.2 and the rest of Complex II occurred at the end of Wari's rule or this architectural complex postdates Wari's collapse. The site's architecture suggests the latter possibility is the more likely. Drawing upon evidence from wall bonding, Anders states that "Complex II was built after construction of the regular buildings of the South Sector," and concedes that its occupation may follow that of the regular architecture (Anders 1986:120). The irregular construction of Complex II contrasts strikingly with the rigidly orthogonal layout of the North and Central Sector of the site. The irregular and unplanned architecture of Complex II represents construction undertaken after the disintegration of centralized political authority in the Ayacucho Valley.

In this light, the evidence of an elite occupation of Complex II reflects not the presence of a Huantino governor ruling under Wari suzerainty, as argued by Anders (1986:657), but rather the activities of a high-status household in the immediate post-Wari interval. To judge from the ceramic assemblage of Complex II, these activities included feasting: $78 \%$ of the vessels recovered from this sector represent forms for the consumption and serving of food (bowls) and maize, beer, or chicha (jars, cups, and spouted bowls) (Anders 1986:658). The high proportion of serving vessels (almost entirely of the Wamanga style) reflects consumption at a supra-household level, though the largess provided by the occupants served the needs of a small-scale Huantino polity rather than that of the defunct Wari state.

Although Anders (1986:617-9) argues that burial within the shaft tomb in Unit 3 of the South Sector was contemporaneous with the occupation of Complex II, she provides no evidence to substantiate this claim. Indeed, the tomb is several meters from the nearest structure and contained no artifacts that might serve as relative chronological indicators. The ${ }^{14} \mathrm{C}$ date from this context (OxA-15374) postdates Wari's fall by several centuries. If, as Anders posits, this tomb was contemporaneous with the occupation of Complex II, then this complex was occupied at least until cal AD 1295-1395 $(68.2 \%)$. However, given the absence of a clear relationship between the tomb and the domestic architecture of Azangaro, this mortuary structure may represent an intrusive post-occupation construction.

Citing the deposition of the unburied skeleton on a bench in the Central Sector as a key piece of evidence, Anders (1986:625-8) has argued that the occupation of Azangaro came to an abrupt and violent end with the collapse of Wari. If the site was suddenly abandoned amidst an orgy of destruction and looting, as the breached walls, robbed benches, and vessels smashed in situ suggest, and the skeleton dates to this abandonment, then Azangaro was not deserted until centuries after Wari's collapse. Such a reconstruction is consistent with the ${ }^{14} \mathrm{C}$ evidence from Complex II and the relative (but it must be emphasized not the absolute) chronology provided by the ceramics, which indicates that the occupations of the Central and South sectors were contemporaneous (Anders 1986:625). This scenario is also consistent with the ceramic and ${ }^{14} \mathrm{C}$ evidence from Qasapampa and Posoqoypata, which suggest that Wamanga-style ceramics remained in use into the 13th century. It is tempting, given the correlation between the dates from Qollana with that of the skeleton in Azangaro's corridor, to connect the appearance of Chanca ceramics in Huanta with this episode of destruction. Might the Chanca have been responsible for the sacking of Azangaro around AD 1300? 
To conclude the discussion of Azangaro, the new ${ }^{14} \mathrm{C}$ AMS assays challenge Anders's (1986) interpretation of the ritual significance of the shaft tomb in the South Sector, social organization at the site, and estimation of the timing of the site's abandonment. It now appears that rather than hosting a brief occupation during Middle Horizon Epoch 2, some areas of the site were occupied following Wari's demise, perhaps until the late 13th century. What Anders interpreted as synchronic variation in the site's use now appears to reflect diachronic variation.

\section{CONCLUSIONS}

This paper makes 3 signification contributions to our understanding of Wari's collapse. First, this research establishes that state authority persisted at the capital until the mid-11th century. Second, it indicates that despite the disintegration of Wari, life in the countryside was not dramatically disrupted. Folk material culture, as epitomized by Wamanga ceramics, settlement patterns, and burial practices of the Valley's occupants, persisted long after Wari's disintegration. Construction of Complex II at Azangaro likely began in this era as well. These findings emphasize that the era of stylistic unity known as the Middle Horizon persisted after Wari's collapse and that the extent and duration of Wari's political hegemony cannot necessarily be inferred from the presence of ceramics. Third, these dates indicate that a major transformation of the Valley's social landscape occurred in the 13th or early 14th century, when the populace adopted new ceramic styles, relocated to their settlements, and embraced new mortuary practices.

Using these new dates, we can more accurately sketch the outline of Ayacucho's prehistory. The forthcoming results of additional AMS assays and the availability of more sophisticated modeling parameters in the next version of the OxCal program should further clarify the chronology of the Ayacucho Valley, shedding more light on the processes of cultural evolution and devolution in the region.

\section{ACKNOWLEDGMENTS}

This research would not have been possible without the aid of many individuals in Peru and the United Kingdom. Joseph Cavalcanti, Abel Cisneros, Celina Moreyra, and Jonathan Cavalcanti assisted in the inventory and analysis of the skeletal material from Qollana. The staff of the Instituto Superior Pedagógico Público in Huanta granted access to the materials from Marayniyoq, Qollana, and Posoqoypata. Marcelina Berrocal and the staff of the Instituto Nacional de Cultura in Ayacucho provided access to the osteological material from Azangaro. Enrique Gonzalez Carré graciously granted access to the materials from Vegachayoq Moqo. Elena Alvarado and José Almorin contributed to the analysis of the osteological material from Huari. Martha Carbrera provided access to the materials from Qasa Pampa housed at the Universidad de San Cristobal de Huamanga. We thank Irela Vallejo and Alberto Carbajal for their patient assistance in the export of the dated samples, as well as Melissa Lund, Elsa Tomasto, and Fernando Fujito at the National Museum of Anthropology. All samples were exported from Peru with the permission of the Instituto Nacional de Cultura in Ayacucho and Lima. We thank William H Isbell, Michael Malpass, and 2 anonymous reviewers for their comments. Last, but certainly not least, we are indebted to the ORAU team: Chris Bronk Ramsey, Tom Higham, Fiona Brock, Martin Humm, Phil Leach, Angela Bowles, Christine Tompkins, and Jane Davies. This research was funded in part by the Rhodes Trust, Merton College Oxford, and a NERC-ORADS grant (2005/1/8) to Tamsin O'Connell. 


\section{REFERENCES}

Anders M. 1986. Dual organization and calendars inferred from the planned site of Azangaro-Wari Administrative strategies [PhD dissertation]. Ithaca: Cornell University.

Anders M. 1991. Structure and function at the planned site of Azangaro: cautionary notes for the model of Huari as a centralized secular state. In: Isbell WH, McEwan GF, editors. Huari Administrative Structure: Prehistoric Monumental Architecture and State Government (Dumbarton Oaks Pre-Columbian Conference Proceedings). Washington, D.C.: Dumbarton Oaks Research Library and Collection. p 165-98.

Bragayrac E. 1991. Archaeological excavations in the Vegachayoq Moqo Sector of Huari. In: Isbell WH, McEwan GF, editors. Huari Administrative Structure: Prehistoric Monumental Architecture and State Government (Dumbarton Oaks Pre-Columbian Conference Proceedings). Washington, D.C.: Dumbarton Oaks Research Library and Collection. p 71-80.

Bronk Ramsey C. 1995. Radiocarbon calibration and analysis of stratigraphy: the $\mathrm{OxCal}$ program. Radiocarbon 37(2):425-30.

Bronk Ramsey C. 2001. Development of the radiocarbon program. Radiocarbon 43(2A):355-63.

Bronk Ramsey C, Higham T, Bowles A, Hedges R. 2004. Improvements to the pretreatment of bone at Oxford. Radiocarbon 46(1):155-63.

DeNiro M. 1985. Postmortem preservation and alteration of in vivo bone collagen isotope ratios in relation to palaeodietary reconstruction. Nature 317(6040):8069.

Finucane B, Maita Agurto P, Isbell WH. 2006. Human and animal diet at Conchopata, Peru: stable isotope evidence for maize agriculture and animal management practices during the Middle Horizon. Journal of Archaeological Science 33(12):1766-76.

Glowacki M. 2005. Dating Pikillacta. In: McEwan GF, editor. Pikillacta: The Wari Empire in Cuzco. Iowa City: University of Iowa Press. p 115-24.

Isbell WH. 1977. The Rural Foundation for Urbanism: Economic and Stylistic Interaction Between Rural and Urban Communities in Eighth-Century Peru. Urbana: University of Illinois Press. 188 p.

Isbell WH. 2000. Repensando el horizonte medio: el caso de Conchopata, Ayacucho, Peru. In: Kaulicke P, Isbell WH, editors. Huari y Tiwanaku: Modelos vs. Evidencias. Boletín de Arqueología PUCP. Volume 4. Lima: Departamento de Humanidades, Especialidad de Arqueología, Pontificia Universidad Católica del Peru. p 9-60. In Spanish.

Isbell WH. 2001. Reflexiones finales. In: Kaulicke P, Isbell WH, editors. Huari y Tiwanaku: Modelos vs. Evidencias. Boletín de Arqueología PUCP. Volume 5. Lima: Departamento de Humanidades, Especialidad de Arqueología, Pontificia Universidad Católica del Peru. p 455-79. In Spanish.
Isbell WH. 2004. Mortuary preferences: a Wari culture case study from Middle Horizon Peru. Latin American Antiquity 15(1):3-32.

Isbell WH, Schreiber KJ. 1978. Was Huari a state? American Antiquity 43(3):372-89.

Isbell WH, Spickard L, Brewster-Wray C. 1991. Architecture and spatial organization at Huari. In: Isbell WH, McEwan GF, editors. Huari Administrative Structures: Prehistoric Monumental Architecture and State Government. (Dumbarton Oaks Pre-Columbian Conference Proceedings). Washington, D.C.: Dumbarton Oaks Research Library and Collection. p 19-53.

Ketterman G. 2001. New dates on the Huari Empire: chronometric dating of the prehistoric occupation of Conchopata, Ayacucho, Peru [unpublished Master's thesis]. Binghamton: State University of New York, Binghamton.

Lumbreras LG. 1974. Las Fundaciones de Huamanga. Lima: Nueva Educación. 115 p. In Spanish.

MacNeish RS, Cook AG, Lumbreras LG, Vierra RK, Nelken-Terner A. 1981. Prehistory of the Ayacucho Basin, Peru. Volume II. Ann Arbor: University of Michigan Press. 279 p.

Martínez G. 1983. Los dioses de los ceros en los Andes. Journal de la Société des Américanistes 69:85-115. In Spanish.

McCormac FG, Hogg AG, Blackwell PG, Buck CE, Higham TFG, Reimer PJ. 2004. SHCal04 Southern Hemisphere calibration, 0-11.0 cal kyr BP. Radiocarbon 46(3): 1087-92.

McEwan G. 1991. Investigations at the Pikillacta site: a provincial Huari center in the valley of Cuzco. In: Isbell WH, McEwan GF, editors. Huari Administrative Structures: Prehistoric Monumental Architecture and State Government (Dumbarton Oaks Pre-Columbian Conference Proceedings). Washington, D.C.: Dumbarton Oaks Research Library and Collection. p 93119.

Menzel D. 1964. Style and time in the Middle Horizon. Nawpa Pacha 2:1-105.

Moseley ME, Nash DJ, Williams PR, deFrance SD, Miranda A, Ruales M. 2005. Burning down the brewery: establishing and evacuating an ancient imperial colony at Cerro Baúl, Peru. Proceedings of the $\mathrm{Na}$ tional Academy of Sciences USA 102(48):17,264-71.

Owen BD. 2005. Distant colonies and explosive collapse: the two stages of the Tiwanaku diaspora in the Osmore Drainage. Latin American Antiquity 16:4580.

Perez I. 2000. Estructuras megaliticas funerarias en el complejo de Huari. In: Kaulicke P, Isbell WH, editors. Huari y Tiwanaku: Modelos vs. Evidencias. Boletín de Arqueología PUCP. Volume 4. Lima: Departamento de Humanidades, Especialidad de Arqueología, Pontificia Universidad Católica del Peru. p 505-48. In Spanish. 
Reimer PJ, Baillie MGL, Bard E, Bayliss A, Beck JW, Bertrand CJH, Blackwell PG, Buck CE, Burr GS, Cutler KB, Damon PE, Edwards RL, Fairbanks RG, Friedrich M, Guilderson TP, Hogg AG, Hughen KA, Kromer B, McCormac G, Manning S, Bronk Ramsey C, Reimer RW, Remmele S, Southon JR, Stuiver M, Talamo S, Taylor FW, van der Plicht J, Weyhenmeyer CE. 2004. IntCal04 terrestrial radiocarbon age calibration, 0-26 cal kyr BP. Radiocarbon 46(3): 1029-58.

Schreiber KJ. 1992. Wari Imperialism in Middle Horizon Peru. Ann Arbor: Museum of Anthropology, University of Michigan. $332 \mathrm{p}$.

Stanish C. 2001. The origin of state societies in South America. Annual Review of Anthropology 30:41-64.

Tiesler Blos V. 1994. Los entierros del Sitio Wari - estudio de una poblacion prehispanica [unpublished report]. Submitted to Peru's National Institute of Cul- ture, Ayacucho office (in possession of author). In Spanish.

Valdez E. 2003a. Las ruinas de Chillukupampa. Warpa 1: 12-8. In Spanish.

Valdez E. 2003b. Pueblos del periodo intermedio tardió. Warpa 3:3-27. In Spanish.

Vivanco C, Perez I, Amorín J. 2003. Qasapampa: un poblado de agriculturas Wari en la frontera de los valles de Huamanga y Huanta. Investigaciones en Ciencias Sociales 1:89-120. In Spanish.

Williams P, Isla J, Nash D. 2001. Cerro Baúl: un enclave Wari en interacción con Tiwanaku. In: Kaulicke P, Isbell WH, editors. Huari y Tiwanaku: Modelos vs. Evidencias. Boletin de Arqueología PUCP. Volume 5. Lima: Departamento de Humanidades, Especialidad de Arqueología, Pontificia Universidad Católica del Peru. p 69-88. In Spanish. 